\title{
Food Trucks Driving Gentrification in Austin, Texas
}

\author{
Petra Lütke ${ }^{1}$ and Robert Lemon ${ }^{2}$
}

\begin{abstract}
The text explores the implicit relationship between food practices and gentrification processes in a neoliberal city. Based on Bourdieu's capital types, the text explores the ways in which one's personal taste in food and urban space can lead to the transformation of whole neighbourboods. In particular, it looks at the role food trucks played in the ways in which an East Austin neighbourbood gentrified from 2012-2020. The research finds that food trucks turn fallow lots into bustling urban spaces and places. Such convivial and vibrant urban settings attract the creative class and drive up property values. We argue that culinary practices, and food trucks in particular, are critical vehicles of the gentrification process.
\end{abstract}

Keywords: food trucks; mobile food; distinction of taste; gentrification; neoliberal urban policies

\section{Food as a Distinction of Taste}

Eating is a daily physical need, and preparation of foods that suit one's taste and consumption is a distinguishing social practice of everyday life. According to Bourdieu (1987), "taste" is not an individual category, but a manifestation of class relations that show up in habitus, in preferences and in everyday practices. From an interdisciplinary perspective, regional origin and gender are also reflected in it. This applies both to auditory and visual as well as to gustatory and olfactory preferences, aversions and habits of people and the differences in their aesthetic evaluation (Lütke, 2019: 218-220).

The symbolic and aesthetic value of food is very individualized - one would think. Yet the taste is not a purely personal matter, as Bourdieu (1987) shows, in his "Distinctions" in which the combination of capital theory, class theory, and aesthetic theory demonstrates the intertwining of taste judgments. According to Bourdieu (1987), the taste of a person results, e.g. in terms of housing, art and eating as an expression of social experiences and learning processes and is seen as socially produced. His habitus concept describes the connection between class and lifestyle and systematically focuses on the interplay of economic, social, cultural and symbolic capital types. Their connection manifests itself in this way in the spheres of lifestyles as variations of taste (Prahl and Setzwein, 2013: 75). In this approach, the concept of distinction plays a key role. The distinction is based on the hypothesis of Bourdieu (1984) that social distinctions are not arbitrary, but correspond to a certain level of social conflict. In particular, Bourdieu considers the subtleties of taste as an important means of distinctions, with which, above all, the ruling class tries to delimit "down": Filter coffee turns into lattemacchiato and small corner shops become organic supermarkets. Trendy food choices are considered an important part of the sophisticated lifestyle. According to Bourdieu (1987) such choices represents one's social status. For example, latte macchiato is a symbol of

\footnotetext{
${ }^{1}$ Petra Lütke, Department of Geography, University of Münster, Germany. E-mail: petra.luetke@uni-muenster.de

${ }^{2}$ Robert Lemon, Department of Geography \& Environment, University of Texas, Austin, USA. E-mail: rdlemon@gmail.com
} 
gentrification in public discourse in general (Hamburger Abendblatt, 2013). The following questions arise: What role does distinctive eating habits play in changing the character of neighbourhoods? And, in what ways do changes in eating habits in a particular area of a city reflect a city's socio-spatial structure? It's no coincidence that the trendy cocktail bars and restaurants that appeal to certain high-income groups and tourists, making a significant contribution to the neighborhood's image, function as emblematic indicators of social change. To answer these questions, we first embed our topic in the theoretical discourse at the intersection of gentrification and food studies. In doing so, we ask what do we know from literature about the role of culinary culture in gentrification processes? In the following part, we present an empirical case study in Austin, Texas. In the fourth and final section, we embed the case study and take up the conceptual debate again to discuss the role of cuisine as an indicator of taste in the process of gentrification.

\section{The Role of Food in Gentrification}

Sociologist Ruth Glass used the term "gentrification" in 1964 to describe the displacement of the working-class by middle-class incomers in neighborhoods of London (Glass, 1964). It has come to refer, in popular and academic accounts, to a host of phenomena. Retaining the sense of changing demographics in urban space, it has also been used to denote, among many other ideas, yuppification or homogenization. Whether or not people have employed the term too loosely, it is clear that gentrification, as a complex conglomeration of processes and attitudes taking place in a huge variety of locations, linking local and global concerns, requires equally complex and various analytical approaches. Reflecting the complex negotiations of structure and agency in urban change, many important studies have adopted ethnographic approaches, focussing on the lived experience of individuals in gentrifying areas. One might think that the many contemporary discourses that feature gentrification in an urban context explore the affective aspects of urban change and to demonstrate how individual consumer and lifestyle choices extricate from wider socioeconomic forces.

Gentrification has many academic definitions. In this study, gentrification is "the process by which higher-income households displace lower-income residents of a neighborhood, changing the essential character and flavor of that neighborhood" (Kennedy and Leonard, 2001: 2). Urban upgrades always involve the displacement of low-income households in the gentrification process. This is closely linked to a capitalist logic that classifies the residential property as a profitable investment. In the prolific literature on gentrification and its urban process, it has just become the "new" middle class synonymous with the discussion of the "emancipated gentrifier" (Lees, 2000: 396). Characteristic of this new middle class was the "new culturally sophisticated, urban class fraction, less conservative than the 'old' middle class. Gentrification is deemed to be a spatial manifestation of these new cultural values" (Lees, 2000: 396).

The increasing gentrification of inner cities can be seen as a socio-spatial expression of economic developments: Young, qualified, mobile consumers, who are often active in the creative sector, eat in various eateries. The reason lies in the marketing of creativity and culture and is an essential part of gentrification (Rofe, 2003; Zukin, 2008). Zukin does not see the presence of artists who promote the process of gentrification in the foreground, but the presence of their taste for authenticity in the product mix, in shop design and in the intangible atmosphere of restaurants, boutiques and gourmet shops (Zukin, 2008: 734). Hence, a closer

Border Crossing 
look into the role cuisine plays in the gentrification process focusing on actors and their practices can offer new and valuable insights. Holm (2012: 671 after Clay, 1979) formulates four ideal phases of gentrification, which summarize the temporal course of the structuralmaterial, social-structural and symbolic revaluation. By incorporating Bourdieu's concepts of capital into Zukin's gentrification research (1990), the four-phase model can also describe urban space as a means of transforming different types of capital (Holm, 2010: 69). The idealtypical four-phase model essentially identifies gentrification as a process that follows a neoliberal logic and transforms cultural capital into economic capital. According to the idealtype model, we ask what role does food and the practice of eating play in the gentrification process?

In the first phase there is an influx of artists, students, creatives and the self-employed into an area with low housing costs. Although the so-called pioneers usually have less economic capital due to their insecure professional situation. They are particularly concerned about personal cultural and social capital. This means that social networking and the use of opportunities for self-development transforms urban space, culturally and infrastructurally, and creates it, as e.g. alternative spaces or clubs. The practice of culinary practices does not seem to play an important role in the everyday life of a neighborhood in this phase of gentrification. But on a closer look, however, it is noticeable that ethnic kitchens are a very early part of gentrification in many neighborhoods around the globe. This is not surprising since the consumption of "authenticity" plays a crucial role in commercial gentrification (Stock, 2014; Tuttle, 2019). While there have been many studies about artists and White creative entrepreneurs as facilitators of urban refurbishment, few studies have focused on the importance of ethnic food and commercial gentrification, e.g. by students. For example, it has been demonstrated for Berlin that ethnic food and cuisines are an integral part of gentrifying neighborhoods (Stock and Schmiz, 2019). The connection between gentrifiers and food was summarized in the 1990s by Jon May (1996) with the phrase "taste of the exotic". As May found, members of a "new culture class" in downtown London used their taste for and experience of exotic food to maintain their class position. These gentrifiers expressed that eating "authentic", exotic foods was the main distinction of their location. As summarized by Cook und Crang (1996: 136), 'ethnic eating' (again where authenticity was the key element) to express their 'classiness'. These urban spaces do not only enable the consumption of food, but also the accompanying a practice of flanerie as a construction of the global (Bridge and Dowling, 2001; Hage, 1997). However, the argument that identity is multilayered, including elements of class, gender, race, and ethnicity, is also important to understanding consumerism. Jackson and Thrift (2005) argue in terms of consumption areas that consumption produces many forms of identities.

In the second phase of gentrification, a symbolic revaluation of the area results, changing the perceptions of neighborhoods of this formerly inconspicuous area. Above all, the new spatial image is also described through increased media attention, such as in travel guides as well as magazine and newspaper reports on hip and upcoming districts. This is also accomplished through trendy brick-and-mortar restaurants or mobile vendors, for which the quarter is visited temporarily. This, in turn, attracts tourists (Gotham, 2005), other artists or cultural professionals to share 
in the consumption of the emerging flair of the neighborhood. According to Bourdieu, the individually incorporated cultural capital of the pioneers has transformed into a space-based cultural capital. This includes the newly created cultural activities and offers of the neighborhood as well as immaterial symbolic spatial images that market the image. A special link between food and gentrification is coffee. Coffee consumption in eclectic, eye-catching environments has become a key component of class identities. The coffee culture in these neighborhoods is anchored locally and refers to an Italian or local way of life. Consuming coffee in such settings often refers to the uniqueness and looseness of an urban environment (Chelcea et al., 2015; Hubbard, 2018).

The third phase of gentrification is characterized by economic upgrading. It is made evident by rising property values, rents, and taxes as the location of apartments are now located within a "special place". Changing neighborhood names and marketing the bustling new vibe of the district are used frequently by real estate agents as a value-adding argument. Modernization measures and the conversion of rented apartments into condominiums close revenue gaps (rent gap) in real estate. The new cultural attractiveness of the area implies an economic added value of the land and apartments, which is also generated by attractive culinary delights in the neighborhood. This not only applies to the establishment of higher-priced restaurants or Gourmet Food Trucks, but also to the establishment of organic supermarkets, such as Whole Foods or Trader Joe's. An integral part of Whole Foods marketing is, for example, the promotion of its alleged commitment to sustainable consumption, as primarily organic products, are sold. This appearance is supposed to imply a sustainable neighborhood development (Joassart-Marcelli and Bosco, 2017). These high-end supermarket chains are focused on growth and profit potential in inner-city neighborhoods. Anguelovski (2015) worked out via Boston, Massachusetts, that these supermarkets operate a "supermarket greenlining". This greenlining illustrates the process of food gentrification and the manipulation of health and sustainability discourses on food by healthy and natural food investors and their supporters (Anguelovski, 2015). Spatial cultural capital will be valorized in this phase by neoliberal logics into economic capital, which can also be called spatial profit. The area is attracting attention not only for the real estate sector but also for higher-income groups interested in sustainable lifestyle and building property, the socalled gentrifiers. Low-income households, including former pioneers who cannot afford rising rents and food costs, must leave the neighborhood.

In the fourth phase of gentrification, the social revaluation and distinction, a displacement of the previous inhabitants, which is related to the symbolic and structural appreciation, is continued by groups with higher incomes who are prepared to pay for the "added value" of the "special place". These higher status groups use their personal economic capital to accumulate symbolic capital. The acquisition of property or a representative apartment in a 'sought-after city center location' serves to differentiate between one's social status by means of status symbols. In the fourth phase, the successive exchange of inhabitants through the influx of mainly the uppermiddle class and the upper classes changes the social structure of the area. Structurally, the area is "segregating" (Holm, 2010: 70). This is shown, e.g. through 
the settlement of higher to high-priced stationary restaurants or the temporary Gourmet Trucks, which serve the consumer cultures of urban scene spaces (Lütke, 2019).

This ideal-type historical model represents a theoretical approach to the complex processes of gentrification, in which individual aspects often overlap. It becomes clear that the practice of eating and drinking, in particular, are symbolic capital which contribute to a districts visual atmosphere, an important role in the imagery of these neighborhoods. The capitalist logic of utilization dominates the discourse on development and becomes the driving force of sociostructural, sociocultural, and urban change. Food can be used in gentrification processes to draw attention to new investors, consumers and visitors. As Lemon (2019) reminds us, culinary practices activate and transform urban spaces.

Lemon (2019) points out, food ${ }^{3}$ spaces socially transform cities and create demand where there was none prior. He posits culinary practices activate urban spaces. Cooking and eating practices create convivial atmospheres, places where people like to come together and share food as well as get to know one another. These positive social relationships around cuisine transcend food and ascribe positive attributes to the surrounding urban setting. What once may have been an abandoned building or lot becomes an inviting social scene. Good food and good company create a demand in which people want to be a part of. It is relatively straightforward to take an overlooked and underused lot with little value and activate it with food trucks. As people flock to the lot and celebrate its culinary diversity, the demand of the space and attractiveness of the residential area appreciates in value.

Sbicca (2018: 3) sees high-quality and expensive food offerings as a driving force of gentrification: "Food offers a particularly visceral entry into the politics and processes of gentrification". This leads us to take a closer look at food and eating practices in the context of neoliberalization and distinction in current gentrification processes. A current trend is eating in public space and on the open street. So we focused on various types of food trucks. As part of an empirical research project in the spring of 2014, on the one hand, 17 mobile food vendors were surveyed on the basis of a guideline interview in East Austin. The surveys focused primarily on sociocultural issues such as the motivation of mobile food vending, working conditions in the food business, and changes in neighborhood development. On the other hand, 44 consumers of the mobile food vendors were part of a survey as well to expand the perspectives of the consumers as well as (participant) observation series of food truck localities. We provided a thick description (Geertz, 1973) of both empirical cases with the focus on one illustrative interview each. We briefly reviewed recent developments in the city of Austin before turning our attention to the ongoing gentrification process in East Austin. This is a neighborhood that has undergone major changes in recent years (Herrick, 2008; Tretter, 2015).

${ }^{3}$ For a postcolonial view on Latino food see for example the books "Food Fight" by Paloma Martinez-Cruz (2019) and "The Taco Truck: How Mexican Street Food Is Transforming the American City by Robert D. Lemon (2019) 
36 Food Trucks Driving Gentrification in Austin, Texas

\section{Mobile Food in Austin: Weirdness and Difference}

\section{Neoliberal Urban Policies: Keep Austin Weird}

Austin, Texas, has a variety of food trucks for various reasons. Overall, US food trucks look back on a long tradition. In the meantime, the mobile food market has become highly differentiated, more flexible and globalized. Since the 19th century, markets, traders, wholesalers, and sellers have been key players in the local economies of a city, providing basic food supplies (Loukaitou-Sideris and Ehrenfeucht, 2009). The American variety of concepts also reflects the cultural diversity of the characteristics: Chuckwagons, Food Carts, Push Carts, Food Trucks, Food Stations, Loncheras, taco trucks, etc. The food truck phenomenon has achieved very broad media attention in the USA and generates approximately $\$ 1.2$ billion revenue (Le, 2020: 4). The growth rate from 2015 to 2020 was about 7.5\% per annum and a further increase in this ever-growing cultural economy is to be expected. Food trucks are almost exclusively viewed positively by the population, approx. 94\% (Petersen, 2014: 30) associate advantages for the neighborhood: e.g. vitalizing roads, offering fresh, healthy and locally sourced food, and also intensifying social contacts in the neighborhood. But also the use of brownfields as intermediate and multiple uses, as well as local employment opportunities, play a role. Meanwhile, the diversity of food trucks reflects social differentiation.

In the context of neoliberal urban policies, the so-called Creative Class according to Richard Florida $(2002,2005)$ plays a special role. His growth theory is based on the assumption that creativity has become the decisive productive force and resource for competitive advantages for companies and cities (Florida, 2005: 5). In two dimensions, creativity becomes a central resource for urban development: Economically, it should stimulate employment and economic growth, and culturally it shall create an attractive, "authentic" mix of subcultural and high culture formats for urban quality of life in order to compete for the creative "human capital" (Talents) will advertise (Merkel, 2012: 71). During this time, Austin emerged as part of a nationwide showcase of successful cities, often topping the list of green cities while also serving as a model for the acclaimed creative city (McTarnaghan, 2015: 51). Within this paradigm, there is a tendency to associate "specific ideals of urban "livability" with the politics of urban economic development, which takes into account the goals of Richard Florida's "Creative Class"'” (McCann, 2008: 2). As creativity is coupled with livability, the narrative goes that the city is "reshaped and repackaged as a consumer and living space that attracts the creative class" (McCann, 2008: 4) in order to be economically competitive. Florida advises with the Creative Class Group, a lucrative consulting firm, cities that want to position themselves in international competition. He is considered a "rock star" of the regeneration of cities and he advised cities such as Barcelona, Brisbane, Dublin, Pamplona and the city of Austin, Texas (Wainwright, 2017). In Austin his strategy is being implemented: The Austin Independent Business Alliance has been working to promote small and medium-sized local businesses and has adopted the slogan "Keep Austin Weird" from a local radio station. On the one hand, they wanted to deliberately present themselves as unusual and "crazy" and, on the other hand, to be open to new business ideas. Particularly promising actors in the cultural and creative sectors should feel addressed, such as the music and media industries (Long, 2009, 2010). Since 1987, the South by Southwest (SXSW) Festival in Austin has been held annually, bringing together exactly those cross-media wishes. These include festivals, conferences and special exhibitions in the fields of music, film and interactive media with 
approximately 28,000 young creatives from 67 nations (SXSW, 2016). Moreover, Austin is the capital of the state of Texas with numerous colleges and other educational institutions. This younger group of educated people helps produce and attract Austin's creative class.

Figure 1. 11th St, East Austin, Texas (Photo: Lütke 2014).

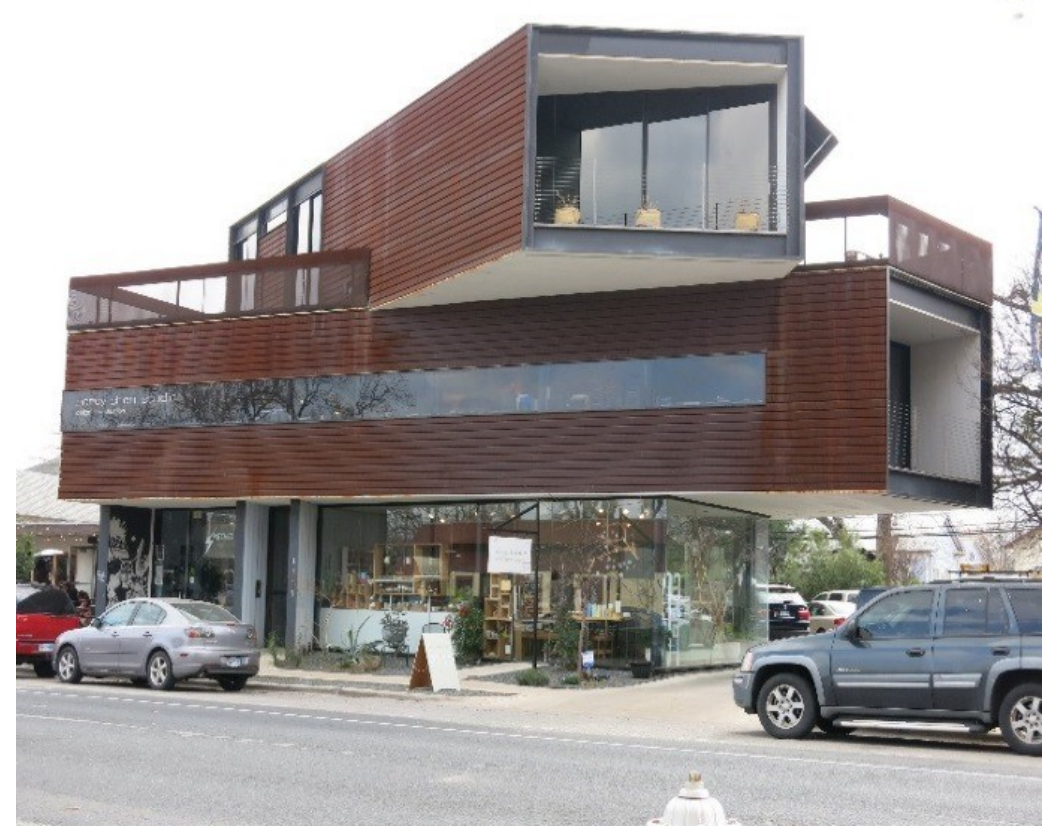

A huge variety of various food trucks can be found in downtown Austin and to the east of Interstate 35 - in the area that is known locally as East Austin. According to a study by the Thomas E. Fordham Institute in 2012, East Austin ranks 5th in the US fastest-gentrifying neighborhoods (Petrilli, 2012). "There is no question, what is happening in Austin is fullblown gentrification, but while some view gentrification as "cultural genocide", others think that they are revitalizing streets and urbanizing disenfranchised residents" (Stimpson, 2016: 4). Since the late 1990s, gentrification and displacement of minorities have been observed in East Austin (Herrick, 2008; Long, 2009, 2010; Swearingen, 2010; Tretter, 2012, 2015). With Austin's urban neighborhoods in high demand as residential locations, East Austin was considered a popular and, above all, affordable residential location. In 2000, the median sales value of a home was $\$ 77,000$, up to $\$ 195,000$ in 2005 (Rice, 2012: 130). This $250 \%$ increase reflects the speed of developments. In part, the typical East Austin detached home-andgarden were replaced with multi-story residential and commercial buildings (figure 1). The rise in house prices correlated with the displacement of the old-established population. In the late 1920s, MacDonald (1993: 168) described East Austin as follows: “(...) about 90 percent or more of the city's ethnic-Mexican population was concentrated in two ethnic clusters, the largest being in East Austin and immediately adjacent to the city's main African-American neighborhood.

Austin, TX has a varied and complex racial and ethnic history. Indeed, the city we know today is superimposed on a racial topography of social injustice. There were as many as 13 freed- 
Figure 2. Changing African-American Landscape in East Austin, 2000 und 2010 (Robinson, 2011a; Data: US Census 2000 and 2010; map slightly changed: emphasizing I35).

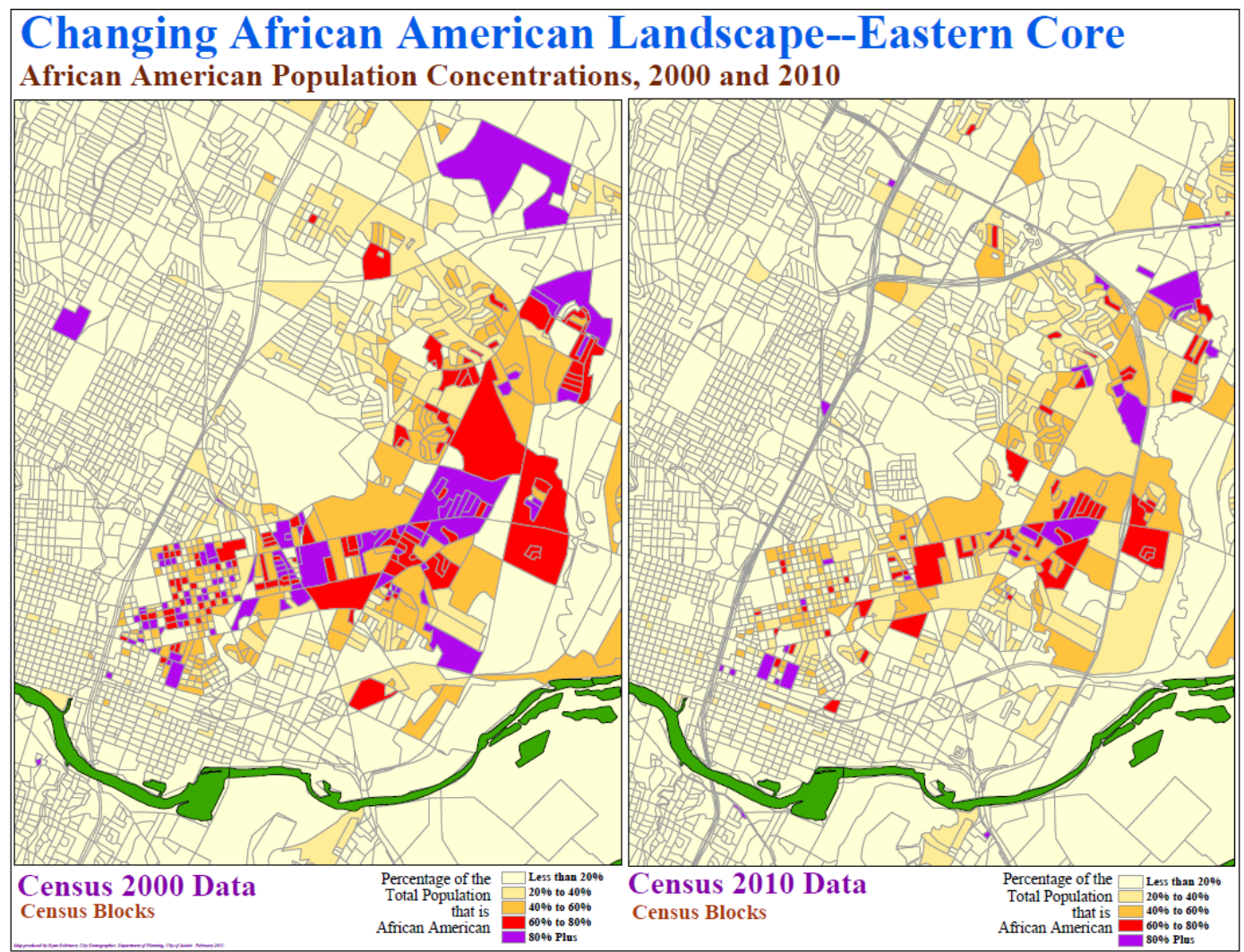

slave communities in the Austin area, many which are considered Austin's premier neighborhoods today (Barnes, 2014; Mears, 2009; Tretter, 2016). In 1928, the city devised within its city plan to displace African Americans to one area of the city, the East Side. ${ }^{4}$ In early 1960s the construction of Interstate 35 cemented the city into two segregated sides. In addition, the construction of Mopac (Loop 1) 5 displaced many Latinos on Austin's west side and moved them near the power plant on the lower East Side. To be sure, the city's present racial spatiality is a product of its discriminatory past. Now through gentrification processes

\footnotetext{
${ }^{4}$ In 1928 the city of Austin commissioned a "Master Plan" that divided the city today. Before 1928, African Americans lived in various enclaves across the city, but the greatest concentration of African Americans was in the area east of what is now the downtown business district. The city's Master Plan was to make this area for African Americans, they were forced to move into this neighborhood. There were the only schools, parks, and other facilities in the city that African Americans were allowed to visit. Since racial segregation public schools and institutions were legal at the time, city guides used this access as a lever to force African Americans into the district without violating the U.S. Constitution. By 1930 , nearly $80 \%$ of the Afro-American population in Austin had moved to the so-called "Negro District" (Tang and Ren, 2014: 7). The historically strong concentration of African American households in East Austin began to erode as early as the 1980s and continued strongly in the mid-1990s (figure 2). In the past 25 years, middle-class African American households have left East Austin and moved to the suburbs and other parts of Austin. The extent of residential segregation for African Americans has decreased significantly with decreasing spatial concentration (City of Austin, 2020).

${ }^{5}$ Loop 1 is a freeway which provides access to the west side of Austin and it is named MoPac Expressway after the Missouri Pacific Railroad.
} 
in East Austin, systematic racism continues to displace Austin's African American and Hispanic populations.

Figure 3. Changing White Landscape in Austin, 2000 und 2010 (Source: Robinson, 2011a; Data: US Census 2000 and 2010; map slightly changed: emphasizing I35)

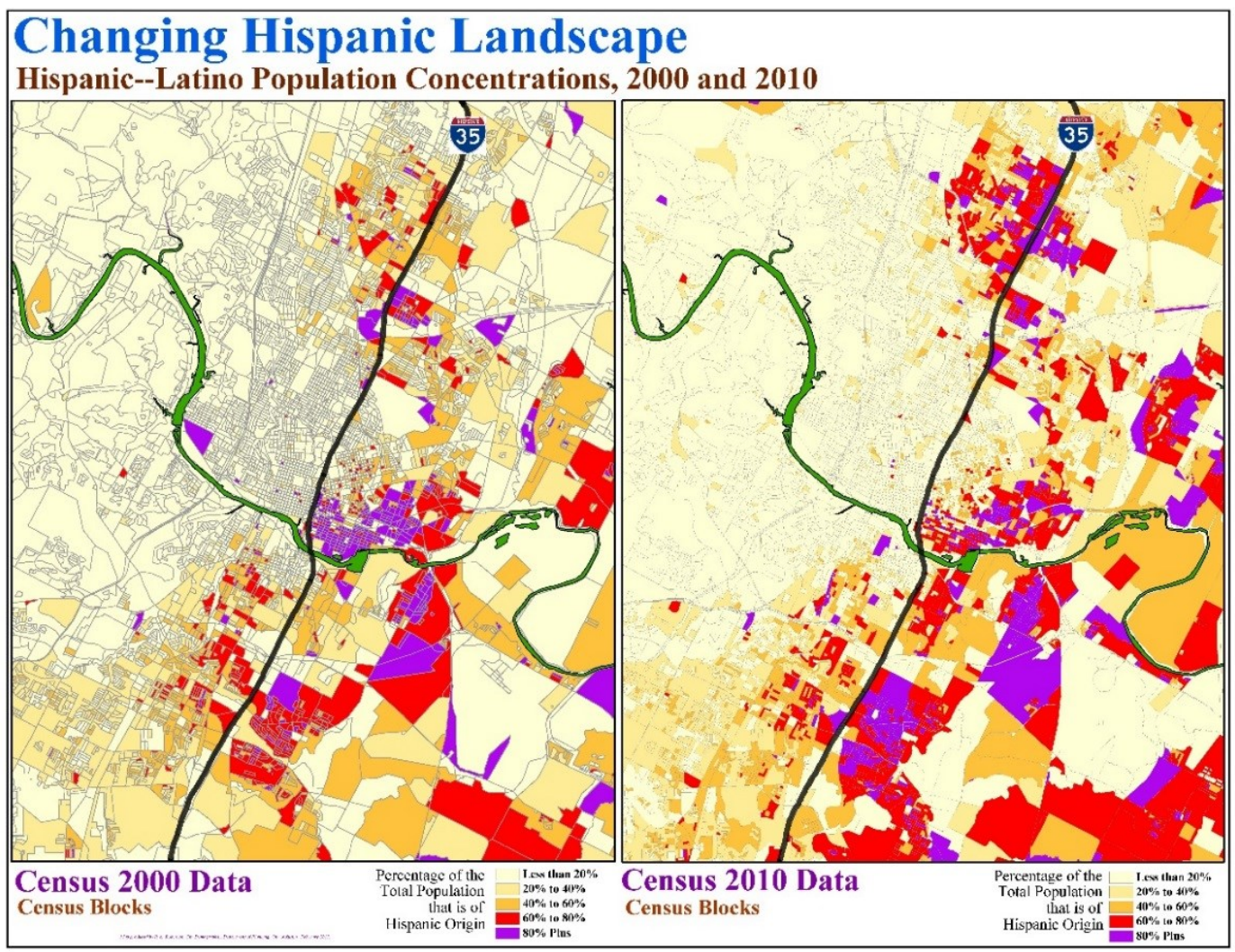

Take for example the Hispanic and African American populations of Austin's East Side. We will define the area as East of Interstate 35, South of Manor Road, and North of the Colorado River. ${ }^{6}$ In 2000 the Black population was 5,476 and Hispanics was 15,261. In 2010 as Austin's population boom began to spill across the freeway to Austin's East Side. The proximity of affordable land near downtown and the closing of Austin's East Side power plant spurred development interest in the East Side. Therefore we argue it was in 2010 that East Austin began its gentrification process. The Black and Hispanic populations then was 3,715 and 11,907 respectively. That means a population decrease of $30 \%$ of Black people and $23 \%$ of Hispanics in East Austin. In 2017 the African American population had further decreased to 3,025 while the Hispanic population is 10,761. In the past 10 years Austin's developing food scene has contributed greatly to this demographic shift. ${ }^{7}$ In this context, the gentrification

\footnotetext{
${ }^{6}$ East Austin is defined as zip Code 78702 (Central East Austin), Census Data 2000 and 2010

7 The increase in the Hispanic population (figure 3) can mainly be observed on the outer eastern and southern edges of Austin. Inner-city neighborhoods, such as East Austin, which were previously Hispanic dominated, are increasingly being replaced by more affluent White populations (figure 4).
} 
processes represent a socio-spatial prototype of postindustrial urban development (Zukin, 1987, 1990), in which current urban developments in East Austin are characterized by the increased emergence of consumer dominated spaces, in contrast to the functional structure of Fordist cities.

Figure 4. Changing White Landscape in Austin, 2000 und 2010 (Robinson, 2011b; Data: US Census 2000 and 2010; map slightly changed: emphasizing I35).

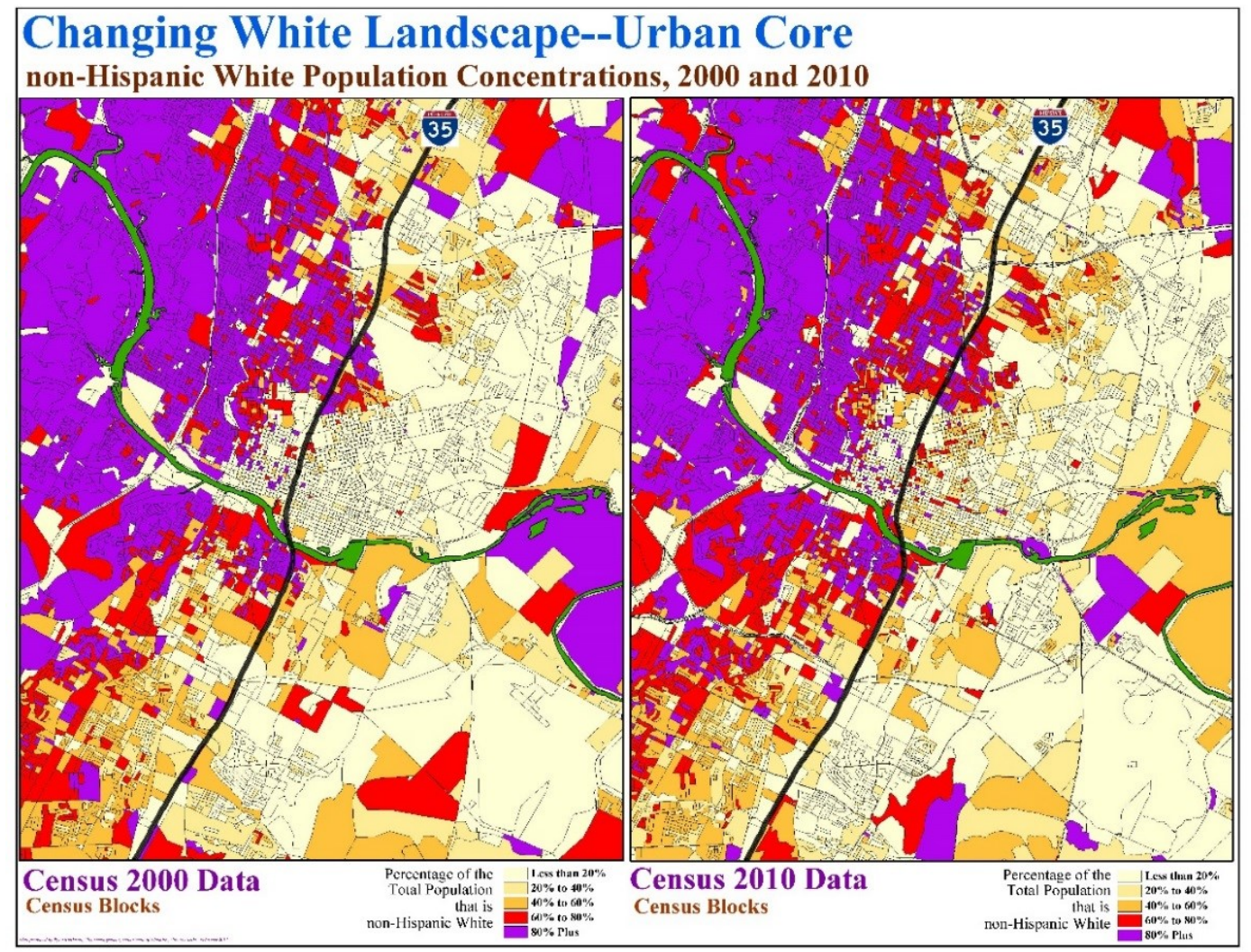

\section{Consuming Difference}

From 2010 to 2020, while the African American and Latino populations dwindled, the number of food trucks in East Austin increased. In Austin, there is no strict regulation as to where food trucks may stay in the short or long term. The city administration only stipulates that the proximity to Brick-and-Mortar restaurants must not be less than 20 feet. The locations in Commercial or Industrial Zoning Districts are, with a few exceptions, such as neighborhood offices, without prior municipal approval for food trucks accessible. This very tolerant "laissez-faire" for mobile food vending is one of the most liberal location policies in the United States and has contributed to both quantitative expansion and a strong differentiation of food trucks (Alvarez, 2016: 6). From windshield surveys, and some help from Yelp, we estimate that there were as many as 60 food trucks or food trailers on the East Side between 2010-2015. The vast majority of the trailers or trucks are owned by Anglos and serve a vast variety of cuisines primarily to a young Anglo clientele. Few, in comparison, of the food trucks or trailers are traditional taco trucks which serve the existing East Side Latino

Border Crossing 
community. It is important to note that prior to 2010 there were only a handful of taco trucks. Trendier boutique food trailers and trucks only began to make their appearance around 2011 on the East Side of the city. This is a remarkable increase in mobile food vending in a span of five to seven years, between 2010 and 2015-2017.

Not only did food truck numbers in East Austin multiply, but the ways in which the food truck spaces themselves refashioned and reappropriated urban space is significant. For example, the road-side locations of the food trucks, the "East Side Fillin' Station" (6th corner Waller Street), a temporary trailer park with various food trucks and seating options, was built on a brownfield site since the end of 2010 / beginning of 2011 (figure 5). Other trucks were so successful that they eventually closed their mobile vending and started a bricks and mortar restaurant. For example, Via 313, a pizza trailer serving Detroit style double layered pepperoni pizza since 2011, opened their own brick and mortar establishment on the same street seven years later. Their transformation from an unassuming trailer to a polished brick-and-mortar restaurant in a span of seven years closely reflects many of the sudden changes in the redevelopment that has upgraded the East Side.

Taco trucks also spur social and cultural change. Not only do the trucks' owners provide Latino's comfort foods from home, they also offer non-Latino consumers cultural diversity through the sale of freshly prepared ethnic street foods, such as tacos and tortas (Lemon, 2016, 2017; Park, 2017). For example, an Anglo visitor of a taco truck remarked: “...this [while eating a taco and drinking a coca cola] is like being in Mexico City, same flavor..." (consumers 16). This indicates a kind of "culinary tourism" (Germann Molz, 2007), which is not necessarily about understanding cultural diversity. Rather, it is about developing a sense of adventure, adaptability, and demostrating an openness to exotic cuisine. Food and drink are mobilized as material symbols of the global in cosmopolitan travel services, through which eaters simultaneously exceed and strengthen the norms of their own culture (Germann Molz, 2007: 77). In addition to these symbolically charged qualities, food trucks also have a social, economic or cultural catalyst function in their temporary local arrangements. On the one hand, there are the Gourmet Food Trucks, who communicate their constantly changing locations (flows) via social media and often in conjunction with several Gourmet Food Truck at festivals or food courts, such as the "East Side Fillin' Station" (Lütke, 2019). On the other hand, there are traditional taco trucks, which seldom change locations. These are rarely found at food truck hubs like the "East Side Fillin' Station". By contrast, the middle-class gourmet food trucks reflect the social order of their everyday routines of the White middle-class in the neighborhood. In the context of hipster culture, crisis, and flexibility work, the food trucks seem to have been rediscovered. The preference for "gourmet Tex-Mex food" and the exoticization and romanticization of the so-called "others" in turn stabilizes their own cosmopolitan identity for the White middle-class. The term hipster is increasingly used to describe the trendy, young, White, middle-class gentrifiers moving into urban working-class neighborhoods (Zukin, 2010a; Zukin et al., 2017). 'Hipsters' appropriation of working-class space is part of their search for "authenticity" and 'edginess' (Douglas, 2012; Zukin, 2010b: 22). Yet the hipster has become a controversial social type, seen as contributing to both the trendiness of gentrifying neighborhoods (Douglas, 2012; Zukin, 2010b; Zukin et al., 2017) and the displacement of working-class residents in the wake of rising rents and property prices (Brown-Saracino and Rumpf, 2011; Langegger, 2016). In Austin, many of these working-class residents happen to be African American. 
Figure 5. History of the "East Side Fillin' Station", 1108 E 6th St, Austin, Texas, USA (source: Google Maps Street View).

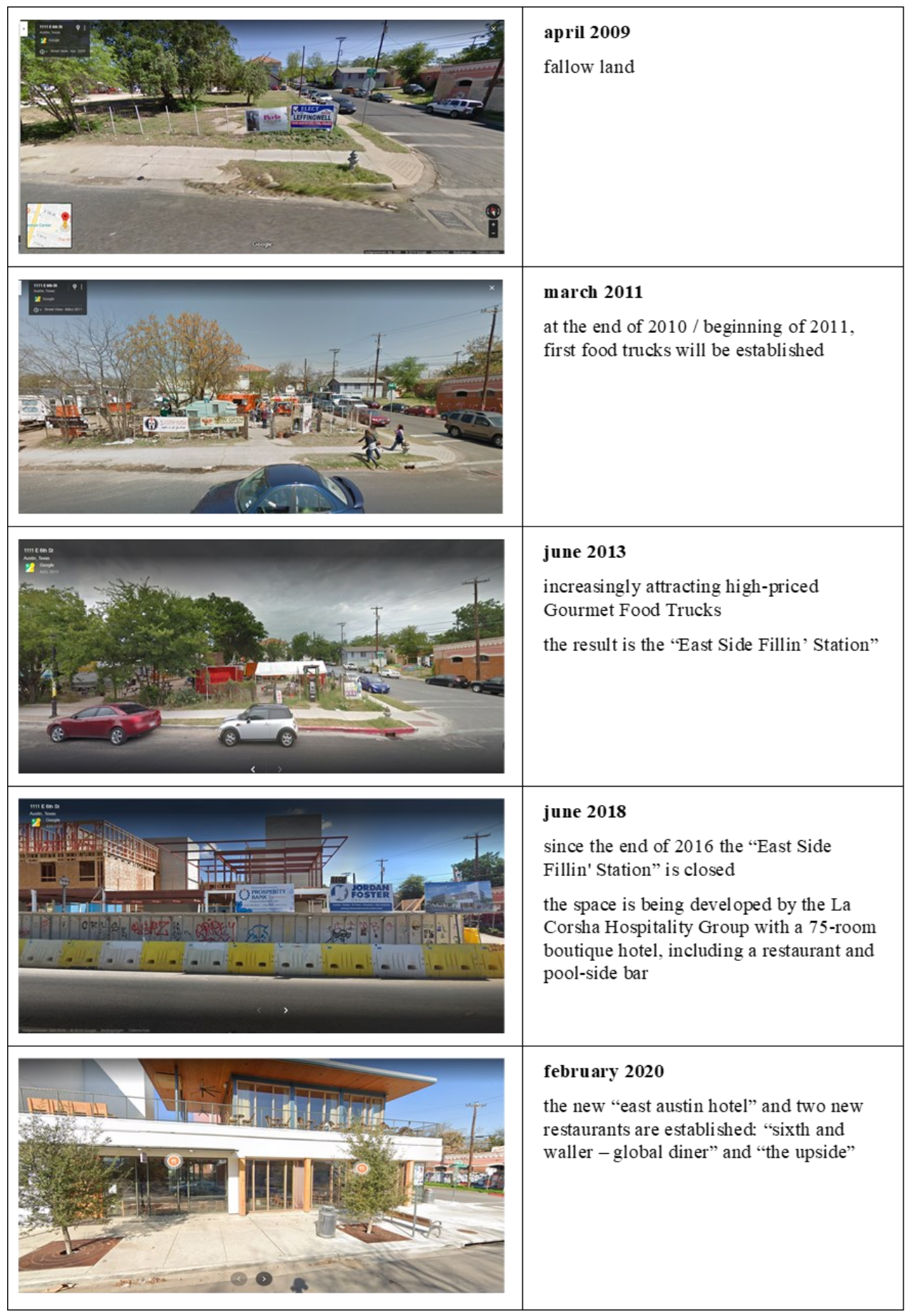


Gentrification of the neighborhood through haute culinary practices also affects some already preexisting food truck establishments. The traditional taco truck could also be found scattered along the streets of East Austin. Latinos mostly own and operate the taco trucks. They mainly serve tacos and tortas to a primary working class Latino clientele. However, they now are making Mexican street foods for the neighborhood's wealthier newcomers. Indeed, the traditional taco truck adds to the "authentic" feel of the district. It helps attracts more people who are interested in eating the exotic and experiencing the grittier working areas of the city. Seen in this way, the taco truck is nourishing its demise.

In addition to tacos and tortas, taco trucks have added American classics to the menu. For example, hamburguesas on the menu represent a Mexican version of the American Hamburger. This mix between Mexican, American and especially Texan cuisine is summarized under the label "Tex-Mex-kitchen" and is popular in Austin; especially to the White middle class: "...that's awesome, I love this Tex-Mex shit [while eating Tex-Mex food], wonderful and original Tex-Mex..." (consumer 31).

Taco truck owners live in a precarious position. Many do not speak English or have citizenship. Of the taco truck owners we interviewed, only one taco vendor had US citizenship, the other vendors did not. More than half (three out of five) had poor language skills and some had entered the US illegally. Because of this, they avoid moving in Englishspeaking areas of Austin so as not to run the risk of being controlled. Four out of five taco truck owners remained primarily at the site. For example, in parking lots of smaller commercial strips, gas stations, or roadside major arterial roads in southern Austin.

Another reason why traditional taco trucks are severely restricted in their mobility is the lack of economic capital. Often, they are dealing with autonomously converted trailers or similar vehicles that are unable to withstand constant movement. Due to a lack of economic capital, spatial performance is rather persistent. Diverse gentrification processes combined with rising gourmet food demand strongly influence or even destroy the social fabric of a neighborhood. In return, the temporary socio-economic arrangements change in such a way that the "East Side Fillin' Station" has been closed since the end of March 2016 in order to give way to a the construction of a multi-story hotel (Chaudhury, 2016). Further upgrading processes of food in East Austin, such as the influx of high-quality food trade, were also in the quarter. Following the disappearance of the "East Side Fillin' Station", Whole Foods, the world's largest organic supermarkets (headquartered in Austin, Texas), moved into East Austin in late 2019 (Chaudhury, 2019). With the influx of gourmet foods, traditional taco trucks and their clientele are pushed out, typically further south and east of downtown Austin.

\section{Gentrifying through Food or Gentrification of Food?}

With his lifestyle analysis, Bourdieu (1987) brings together the class-specific distribution of taste preferences with the question of the mechanisms of the reproduction of social inequality. His key finding in his analysis is that every practice, not just cultural consumption but also the way we eat, is part of a lifestyle and has a symbolic dimension. In this way, eating and the practice of eating in relation to and in contrast to others can be understood as a distinction. Through distinction and by means of "fine differences", some hope to define themselves and differentiate themselves from others, while the others nourish the illusion of a higher status through pretension and ever new copies of status symbols. The view of food and eating food is always directed towards food in relation to processes of production regulation, 
representation, identity and consumption as well as the interplay of material and symbolic aspects that come together around cuisine. The urban political interdependence between food, the practice of eating, and gentrification suggests that "food gentrification" can be interpreted in myriad ways. We can look at consuming food in two ways: food as a gentrifier or food as the gentrified.

Food can be an indicator of progressive gentrification in the first sense. Food trucks attract the White middle-class and the creatives in a neighborhood. Eating at a food truck is not just a culinary experience, but also a postmodern, trendy practice that stands for a progressive and hip lifestyle (Agyeman et al., 2017: 314-315). Indeed, food practices in the field of gastronomy has myriad of symbolic meanings (Sato et al., 2017: 180). In terms of cuisine, both food and food trucks were culturally appropriated by and for the predominant companies, and thus gentrified in the second sense. There are gastronomic studies that focused on food's symbolic systems and representations were theoretical and discussed symbolism from the perspective of the gastronomy field. For example, Carvalho and Luz (2011) observed the interaction between factors influencing the permanent creation of new meanings for food and explored the habitus associated with two styles of eating: "natural" and "fast-food". Other gastronomic studies (e.g. Costa et al., 2014) show that natural, organic foods were used as a symbol of identity or status. For organic food shoppers, the social value of food was related to the place where the food was purchased (community supported agriculture or supermarket) and whether consumers or producers exhibited other "green" behaviors to corroborate their concern for sustainability. So "this development goes hand in hand with an extensive commercial gentrification of inner-city neighborhoods that entail commodified versions of authenticity: from 'handmade' bags to retro bars and 'authentic' ethnic food." (Stock and Schmiz, 2019: 1).

In addition, food trucks can be upgraded not only on the operator's side but also on the consumer's side. With the popularity and proliferation of food trucks, meal prices can increase and be socially exclusive. The gastronomic institutionalization of food and the practice of eating ensures a greater quality of stay and permanent accessibility of neighborhoods and is at the same time the expression and mirror of social change processes. This opens up the possibility of integrating socio-spatial and socio-political developments through the food perspective on gentrification processes. In the following, we would like to discuss two explanatory logics.

Just as there are different political-economic explanations for gentrification in general, there are different explanations as to why and how eating is part of this process. The approach of "green gentrification" or "ecological gentrification" interpreted food and the practice of eating as inherent components and of gentrification processes (Checker, 2011; Dooling, 2009; Gould and Lewis, 2012; Sbicca, 2018). The focus is on social processes in which local stakeholders, with healthy food and sustainable food, generate economic interests in order to attract wealthier residents and displace low-income residents. This can happen in the form of the mobile Gourmet Food Trucks (Lütke, 2019) or by the establishment of stationary food retailers, such as the high-end organic supermarket chain, Whole Foods (Anguelovski, 2015). However, increasing urban food production, such as urban gardening or roof farming, can also lead to displacement processes. In addition, farmer markets and community gardens are mainly located in affluent and gentrifying areas, demonstrating the increasing appropriation 
of alternative food spaces by middle-class and cultural elites (Joassart-Marcelli and Bosco, 2017).

An approach to how the role of food and eating can be seen in the process of gentrification is pursued by Cohen (2018). For him, food plays an important role in gentrification, using the "foodie culture" as an indicator of the "investment maturity" of an area. Investors can see from food facilities in a neighborhood or a street, whether an investment in the real estate market could be worthwhile. Thus, the food policy of a municipality plays an important role in gentrification, by preventing measures against gentrification-sensitive food facilities (Gaspard, 2019). Measured by the high relevance of urban politics and everyday life, the importance of food and eating has rarely been the focus of systematic scientific investigations. Neal (2016: 1), therefore, means "food is not only a functional good, but also a cultural object - consumed not only for these nutrients, but also for its symbolic and aesthetic value". The driving cause of gentrification is a product that confirms the authenticity of consumer goods. This authenticity is an urban marketing and framework concept that plays a central role in late capitalist urban space because it is based on the production of value in the symbolic economy (Zukin, 2010a).

Gentrification is an ongoing cultural and economic process. As cultural and culinary preferences gradually change, so too does the neighborhood. In this article we argued that the taste of food is both literal and figurative. The flavor of food pleases our senses and this pleasure transcends our palate to encompass our social setting and surrounding aesthetics. Cuisine and urban space are enmeshed and consumed simultaneously.

To consume good food is to be content. People are drawn to cuisine and culinary spaces that create a convivial atmosphere. To belong to the social class that fashions such creative culinary spaces is certainly a sign of distinction. In other words, to taste innovative foods is on the same level as to have good taste in the neighborhoods we choose to reside in. Good taste in food translates to good taste in urban space, which further causes a demand for such spaces and increases property values and property taxes. For a neighborhood to gentrify, there certainly must be a cultural demand as well as an economic incentive. The urban environment transforms both physically and socially through novel foods and the culinary practices associated with producing and consuming such foods. And so, good cooking from food trucks is quite often the turnkey to driving gentrification.

\section{References}

Agyeman, J., Matthews, C. and Sobel, H. (2017). "Reflections”. In: J. Agyeman, C. Matthews and H. Sobel (eds.) Food Trucks, Cultural Identity, and Social Justice. From Loncheras to Lobsta Love, Cambridge: MIT Press.

Alvarez, N. (2016). "Regulating the Food Truck Industry: An Illustration of Proximity and Sanitation Regulations". Journal of Food, Law \& Policy, 12 (1): 1-15.

Anguelovski, I. (2015). "Healthy Food Stores, Greenlining and Food Gentrification: Contesting New Forms of Privilege, Displacement and Locally Unwanted Land Uses in Racially Mixed Neighborhoods". International Journal of Urban and Regional Research, 39 (6): 1209-1230.

Barnes, M. (2014, June 21). Clarksville and Wheatville Were Not Austin's Only Freedmen Towns. Austin American-Statesman. https://www.statesman.com/article/20140621/NEWS/306219682.

Bourdieu, P. (1984). Distinction: A Social Critique of the Judgement of Taste. Translated and edited by Richard Nice. London: Routledge.

Bourdieu, P. (1987). Die feinen Unterschiede: Kritik der gesellschaftlichen Urteilskraft. Frankfurt am Main: Suhrkamp. 
Bridge, G. and Dowling, R. (2001). "Microgeographies of Retailing and Gentrification”. Australian Geographer, 32 (1): 93-107.

Brown-Saracino, J. and Rumpf, C. (2011). "Diverse Imageries of Gentrification: Evidence from Newspaper Coverage in Seven U.S. Cities, 1986-2006". Journal of Urban Affairs, 33 (3): 289-315.

Carvalho, M. C. d. V. S. and Luz, M. T. (2011). "Symbolism on "Natural" in Food". Ciência \& Saúde Coletiva, 16 (1): 147-154.

Chaudhury, N. (2016, February 12). Wonderland and East Side Fillin' Station Will Shutter For La Corsha's East Austin Hotel [Update]. Eater Austin. https://austin.eater.com/2016/2/12/10978630/wonderlandeast-side-fillin-station-food-truck-park-shutters-la-corsha-hospitality-group.

Chaudhury, N. (2019, January 15). Whole Foods Market Is Opening in East Austin Instead of 365 by Whole Foods. Eater Austin. https://austin.eater.com/2019/1/15/18184241/whole-foods-market-east-austinplaza-saltillo-365-news.

Checker, M. (2011). "Wiped Out by the "Greenwave": Environmental Gentrification and the Paradoxical Politics of Urban Sustainability”. City \& Society, 23 (2): 210-229.

Chelcea, L., Popescu, R. and Cristea, D. (2015). "Who Are the Gentrifiers and How Do They Change Central City Neighbourhoods?: Privatization, Commodification, and Gentrification in Bucharest". Geografie, 120 (2): 113-133.

City of Austin (2020). A City Plan for Austin 1928, Master Plan. Retrieved from ftp://ftp.austintexas.gov/GISData/planning/compplan/1927_Plan.pdf.

Clay, P. L. (1979). Neighborhood Renewal: Middle-Class Resettlement and Incumbent Upgrading in American Neighborboods. Lexington: Heath.

Cohen, N. (2018). "Feeding or Starving Gentrification: The Role of Food Policy". CUNY Urban Food Policy Institute, 5: 1-10. https://www.cunyurbanfoodpolicy.org/news/2018/3/27/feeding-or-starvinggentrification-the-role-of-food-policy.

Cook, I. and Crang, P. (1996). "The World On a Plate”. Journal of Material Culture, 1 (2): 131-153.

Costa, S., Zepeda, L. and Sirieix, L. (2014). "Exploring the Social Value of Organic Food: A Qualitative Study in France". International Journal of Consumer Studies, 38 (3): 228-237.

Dooling, S. (2009). "Ecological Gentrification: A Research Agenda Exploring Justice in the City". International Journal of Urban and Regional Research, 33 (3): 621-639.

Douglas, G. C. C. (2012). "The Edge of the Island: Cultural Ideology and Neighbourhood Identity at the Gentrification Frontier”. Urban Studies, 49 (16): 3579-3594.

Florida, R. L. (2002). The Rise of the Creative Class: And How It's Transforming Work, Leisure, Community, and Everyday Life. New York: Basic Books.

Florida, R. L. (2005). Cities and the Creative Class. New York: Routledge.

Gaspard, A. (2019, February 21). Slowing Down Urban Food Gentrification. Urban Food Futures. https://urbanfoodfutures.com/2019/02/21/gentrification/.

Geertz, C. (1973). The Interpretation of Cultures. New York: Basic Books.

Germann Molz, J. (2007). "Eating Difference”. Space and Culture, 10 (1): 77-93.

Glass, R. (1964). "Aspects of Change". In: The Centre for Urban Studies (ed.) London: Aspects of Change, London: MacGibbon \& Kee.

Gotham, K. F. (2005). "Tourism Gentrification: The Case of New Orleans' Vieux Carre (French Quarter)". Urban Studies, 42 (7): 1099-1121.

Gould, K. and Lewis, T. (2012). “The Environmental Injustice of Green Gentrification”. In: T. Shortell and J. N. DeSena (eds.) The World in Brooklyn. Gentrification, Immigration, and Ethnic Politics in a Global city, Lanham: Lexington Books.

Hage, G. (1997). "At Home in the Entrails of the West: Multiculturalism Ethnic Food and Migrant HomeBuilding”. In: H. Grace (ed.) Home/World. Space, Community and Marginality in Sydney's West, Annandale: Pluto Press.

Hamburger Abendblatt (2013, June 15). Die Stadtteiler. Hamburger Abendblatt. https://www.abendblatt.de/hamburg/magazin/article117146884/Die-Stadtteiler-Gentrifizierungoder-Aufwertung.html.

Herrick, C. (2008). "To the West and East of Interstate-35: Obesity, Philanthropic Entrepreneurialism, and the Delineation of Risk in Austin, Texas". Environment and Planning A: Economy and Space, 40 (11): 27152733.

\section{Border Crossing}


Holm, A. (2010). „Gentrifizierung und Kultur: zur Logik kulturell vermittelter Aufwertungsprozesse“. In: C. Hannemann, V. Kirchberg, H. Glasauer, J. Pohlan and A. Pott (eds.) Jabrbuch StadtRegion 2009/2010. Schwerpunkt: Stadtkultur und Kreativität, Opladen, Farmington Hills: Verlag Barbara Budrich.

Holm, A. (2012). "Gentrification”. In: F. Eckardt (ed.) Handbuch Stadtsoziologie, Wiesbaden: VS Verlag für Sozialwissenschaften.

Hubbard, P. (2018). "Retail Gentrification”. In: L. Lees and M. Phillips (eds.) Handbook of Gentrification Studies, Cheltenham: Edward Elgar Publishing.

Jackson, P. and Thrift, N. (2005). “'Geographies of Consumption””. In: D. Miller (ed.), Material cultures. Acknowledging Consumption. A Review of New Studies, London: Routledge.

Joassart-Marcelli, P. and Bosco, F. J. (2017). "Alternative Food and Gentrification”. In: W. Curran and T. Hamilton (eds.) Just Green Enough. Urban Development and Environmental Gentrification, London: Routledge.

Kennedy, M. and Leonard, P. (2001). Gentrification: Practice and politics. Washington, DC: Local Initiatives Support Corporation Center for Homeownership and Knowledge Sharing Initiative. New York: LISC.

Langegger, S. (2016). "Right-of-Way Gentrification: Conflict, Commodification and Cosmopolitanism". Urban Studies, 53 (9): 1803-1821.

Le, T. (2020). Green Light: Growing Household Income and Changing Consumer Preferences Will Likely Spur Industry Growth. IBISWorld: US Industry (Specialized) Report OD4322. Los Angeles.

Lees, L. (2000). “A Reappraisal of Gentrification: Towards a 'Geography of Gentrification"'. Progress in Human Geography, 24 (3): 389-408.

Lemon, R. D. (2016). "The Budding Aromas from Taco Trucks: Taste and Space in Austin, Texas". Transnational Marketing Journal, 4 (2): 100-109.

Lemon, R. D. (2017). “The Spatial Practices of Food Trucks”. In: J. Agyeman, C. Matthews and H. Sobel (eds.) Food Trucks, Cultural Identity, and Social Justice. From Loncheras to Lobsta Love, Cambridge: MIT Press.

Lemon, R. D. (2019). The Taco Truck: How Mexican Street Food Is Transforming the American City. Urbana: University of Illinois Press.

Long, J. (2009). "Sustaining Creativity in the Creative Archetype: The Case of Austin, Texas". Cities, 26 (4): 210-219.

Long, J. (2010). Weird City: Sense of Place and Creative Resistance in Austin, Texas. Austin: University of Texas Press.

Loukaitou-Sideris, A. and Ehrenfeucht, R. (2009). Sidewalks: Conflict and Negotiation over Public Space. Cambridge: MIT Press.

Lütke, P. (2019). "Die Praxis temporärer Ökonomien im Quartier - Hubs, Flows und Persistencies des „mobile food vending“ in den USA“. In: O. Niermann, O. Schnur and M. Drilling (eds.), Quartiersforschung. Ökonomie im Quartier. Von der sozialräumlichen Intervention zur Postwachstumsgesellschaft, Wiesbaden: Springer Fachmedien Wiesbaden.

MacDonald, J. (1993). Race Relations in Austin, Texas, 1917-1929. PhD thesis, University of Southampton, Southampton, UK.

Martinez-Cruz, P. (2019). "Food Fight!: Millennial Mestizaje Meets the Culinary Marketplace”. University of Arizona Press.

May, J. (1996). "'A Little Taste of Something More Exotic': The Imaginative Geographies of Everyday Life". Geography, 81 (1): 57-64.

McCann, E. J. (2008). "Livable City/Unequal City: The Politics of Policy-Making in a "Creative » Boomtown”. Revue Interventions économiques. Papers in Political Economy (37): 1-18.

McTarnaghan, S. (2015). "Development and Displacement: Single Family Home Demolitions in Central East Austin, 2007 to 2014". Planning Forum, 16: 47-65.

Mears, M. M. (2009). And Grace Will Lead me Home: African American Freedmen Communities of Austin, Texas, 1865 - 1928. Lubbock: Texas Tech University Press.

Merkel, J. (2012). "Kreative Milieus”. In: F. Eckardt (ed.) Handbuch Stadtsoziologie, Wiesbaden: VS Verlag für Sozialwissenschaften.

Neal, Z. P. (2016). “Culinary Deserts, Gastronomic Oases: A Classification of US Cities”. Urban Studies, 43 (1): $1-21$.

Park, K. (2017). "Ethnic Foodscapes: Foreign Cuisines in the United States". Food, Culture \& Society, 20 (3): 365-393. 
48 Food Trucks Driving Gentrification in Austin, Texas

Petersen, D. (2014). Food Truck Fever: A Spatio-Political Analysis of Food Truck Activity in Kansas City, Missouri. $\mathrm{PhD}$ thesis, Kansas State University, Manhatten, KS.

Petrilli, M. J. (2012, November 06). The Fastest-Gentrifying Neighborhoods in the United States. Thomas B. Fordham Institute. https://fordhaminstitute.org/national/commentary/fastest-gentrifyingneighborhoods-united-states.

Prahl, H.-W. and Setzwein, M. (2013). Soziologie der Emährung. Wiesbaden: VS Verlag für Sozialwissenschaften.

Rice, J. (2012). Distant Publics: Development Rhetoric and the Subject of Crisis. Pittsburgh: University of Pittsburgh Press.

Robinson, R. (2011a). Changing Hispanic Landscape: Hispanic-Latino Population, 2000 and 2010. Austin, TX: Planning and Zoning Department of The City of Austin.

Robinson, R. (2011b). Changing White Landscape - Urban Core: non-Hispanic White population concentrations, 2000 und 2010. Austin, TX: Planning and Zoning Department of The City of Austin.

Rofe, M. W. (2003). "'I Want to be Global': Theorising the Gentrifying Class as an Emergent Elite Global Community". Urban Studies, 40 (12): 2511-2526.

Sato, d. M. P., Gittelsohn, J., Unsain, R. F., Roble, O. J. and Scagliusi, F. B. (2017). "The use of Pierre Bourdieu's Distinction Concepts in Scientific Articles Studying Food and Eating: A Narrative review". Appetite, 96: 174-186.

Sbicca, J. (2018). Food Justice Now!: Deepening the Roots of Social Struggle. Minneapolis: University of Minnesota Press.

Shilling C. (1997). The Undersocialised Conception of the Embodied Agent in Modern Sociology. Sociology, 31(4):737-754.

South by Southwest (SXSW) (2016). Official Homepage. Retrieved 12 May 2020 from https://www.sxsw.com/.

Stimpson, K. S. (2016). Gentrification by Design: Rhetoric, Race, and Style in Neigbborbood "Revitalization". PhD thesis, University of Texas at Austin, Austin, TX.

Stock, M. (2014). Der Geschmack der Gentrifizierung: Arabische Imbisse in Berlin. Urban Studies. Wiesbaden: transcript Verlag.

Stock, M. and Schmiz, A. (2019). "Catering Authenticities: Ethnic Food Entrepreneurs as Agents in Berlin's Gentrification". City, Culture and Society, 18: 1-8.

Swearingen, W. S. (2010). Environmental City: People, Place, Politics, and the Meaning of Modern Austin. Austin: University of Texas Press.

Tang, E. and Ren, C. (2014). Outlier: The Case of Austin's DecliningAfrican-American Population. Issue Brief First in a Series of the The Institute for Urban Policy Research \& Analysis. Austin.

Tretter, E. M. (2012). Austin Restricted: Progressivism, Zoning, Private Racial Covenants, and the Making of a Segregated City. Austin: The University of Texas at Austin. https://repositories.lib.utexas.edu/handle/2152/21232.

Tretter, E. M. (2015). "The Environmental Justice of Affordable Housing: East Austin, Gentrification, and Resistance". In: C. Isenhour, G. McDonogh and M. Checker (eds.), New Directions in Sustainability and Society. Sustainability in the Global City. Myth and Practice, Cambridge: Cambridge University Press.

Tretter, E. M. (2016). Shadows of a Sunbelt City: The Environment, Racism, and the Knowledge Economy in Austin. Geographies of justice and social transformation: Vol. 27. Athens: The University of Georgia Press.

Tuttle, S. (2019). "Producing Diverse and Segregated Spaces: Local Businesses and Commercial Gentrification in Two Chicago Neighborhoods". City \& Community, 18 (1): 1-25.

Wainwright, O. (2017, October 26). 'Everything is Gentrification Now'. The Guardian. https://www.theguardian.com/cities/2017/oct/26/gentrification-richard-florida-interview-creativeclass-new-urban-crisis.

Zukin, S. (1987). "Gentrification: Culture and Capital in the Urban Core". Annual Review of Sociology, 13 (1): 129-147.

Zukin, S. (1990). "Socio-Spatial Prototypes of a New Organization of Consumption: The Role of Real Cultural Capital". Sociology, 24 (1): 37-56.

Zukin, S. (2008). "Consuming Authenticity: From Outposts of Difference to Means of Exclusion”. Cultural Studies, 22 (5): 724-748.

Zukin, S. (2010a). "Gentrification as Market and Place”. In: J. Brown-Saracino (ed.) The Gentrification Debates, New York: Routledge.

Zukin, S. (2010b). Naked City: The Death and Life of Authentic Urban Places. Oxford: Oxford University Press.

Border Crossing 
Zukin, S., Lindeman, S. and Hurson, L. (2017). "The Omnivore's Neighborhood?: Online Restaurant Reviews, Race, and Gentrification". Journal of Consumer Culture, 17 (3): 459-479. 